\title{
Progressive multifocal leukoencephalopathy
}

\section{A 25-year retrospective cohort study}

Pria Anand, MD, Gladia C. Hotan, BS, Andre Vogel, BA, Nagagopal Venna, MD, and Farrah J. Mateen, MD, PhD

Neurol Neuroimmunol Neuroinflamm 2019;6:e618. doi:10.1212/NXI.0000000000000618

\author{
Correspondence \\ Dr. Anand \\ pria.anand@gmail.com
}

\begin{abstract}
Objective

To characterize the risk factors, clinical course, and treatment of patients with progressive multifocal leukoencephalopathy (PML) diagnosed and followed over a 25-year epoch at 2 academic hospitals.
\end{abstract}

\section{Methods}

Patients with a definite diagnosis of PML were identified by positive CSF PCR for JC virus or histopathology between January 1, 1994, and January 1, 2019. Demographic and PML-specific variables were recorded on symptomatic presentation and at follow-up, including risk factors, clinical outcome, neuroimaging findings, and modified Rankin Scale (mRS) score at last follow-up.

\section{Results}

There were 91 patients with confirmed PML. HIV infection was the most common risk factor, identified in $49 \%(n=45)$. Other frequent risk factors included lymphoma, leukemia, or myelodysplasia, identified in $31 \%$ of patients $(n=28)$; exposure to chemotherapeutic medications $(30 \%, \mathrm{n}=27)$; and exposure to monoclonal antibody therapies $(19 \%, \mathrm{n}=17)$. Thirty percent of the cohort was alive at the time of censoring, with a median mRS of 2 points, indicating slight disability at last follow-up. Median survival following PML diagnosis in HIVinfected patients was longer than in HIV-uninfected patients (1,992 vs 101 days, $p=0.024$ ). Forty patients survived more than 1 year after PML symptom onset, of whom 24 were HIV infected (60\%). Thirteen patients survived more than 10 years after PML symptom onset, all HIV infected, of the 59 patients diagnosed before June 1, 2009, and eligible for 10-year survivor status $(22 \%)$.

\section{Conclusions}

We add to the limited literature on PML by reporting its epidemiology in a large observational cohort. These parameters may be useful for future clinical trials that measure survival and clinical outcomes. 


\section{Glossary}

AAN = American Academy of Neurology; cART = combined antiretroviral therapy; IRIS = immune reconstitution inflammatory syndrome; $\mathbf{m R S}=$ modified Rankin Scale; PML = progressive multifocal leukoencephalopathy; RRMS = relapsing-remitting MS.

Progressive multifocal leukoencephalopathy (PML) is a demyelinating disease of the CNS caused by reactivation of JC virus leading to oligodendrocyte destruction. Similar to other human polyoma viruses, JC virus is an opportunistic pathogen, with PML manifesting primarily in patients with innate immunodeficiency or taking immunomodulatory medications. The pathology of PML was first reported in 1958 in a patient with chronic lymphocytic lymphoma. ${ }^{1}$ By 1982 , the syndrome had been characterized in HIV-infected patients. ${ }^{2}$ In 2005, PML was first reported in patients treated with natalizumab, a monoclonal antibody approved by the Food and Drug Administration to treat relapsing-remitting MS (RRMS). ${ }^{3,4}$

PML has been reported in association with rheumatologic diseases, lymphoreticular malignancies, and post-organ transplantation immunosuppression, and less frequently, in cases without recognized immunosuppression. As new immunosuppressive therapies are introduced and used increasingly broadly across disease states, PML has been described in association with rituximab, cyclophosphamide, methotrexate, mycophenolate mofetil, dimethyl fumarate, fingolimod, and cyclosporine. ${ }^{5-7}$

Treatment options for PML are limited. Withdrawal of immunosuppressive medications and, in the case of HIVinfected individuals, provision of antiretroviral therapy offer the only clear survival benefit. ${ }^{8}$ Previous studies have explored the efficacy of 5-hydroxytryptamine antagonists including mirtazapine and risperidone, nucleoside analogs including cidofovir and cytosine arabinoside, and biological therapies including interferon alpha, without proven efficacy. ${ }^{9-12}$ More recently, favorable outcomes have been reported in patients treated with immune checkpoint inhibitor therapy ${ }^{13-15}$ and infusion of virus-specific T cells. ${ }^{16}$

Although large cohorts of patients with PML in the setting of natalizumab have been described, ${ }^{17,18}$ most of the literature on diverse etiologies of PML in recent decades has been limited to small case series and individual reports, which are subject to publication bias based on either unexpectedly favorable or unfavorable outcomes. ${ }^{19,20}$ With the new promise of effective therapy for this devastating disease, understanding the diverse presentations of PML is increasingly important because early manifestations may be difficult to recognize but are most amenable to treatment. Here, we report the risk factors and outcomes in a cohort of patients diagnosed with PML and followed at 2 tertiary care hospitals in the United States over a 25-year period.

\section{Methods}

\section{Ethics}

The study protocol was approved by the Partners Healthcare Institutional Review Board of Massachusetts General Hospital.

\section{Patient identification}

Patients were identified by searching the Partners Health Care Research Patient Data Registry system using the International Classification of Diseases 9 th and 10th edition diagnostic codes for PML (046.3, A81.2). All patients who were diagnosed with PML and presented to Massachusetts General Hospital or Brigham and Women's Hospital between January 1, 1994, and January 1, 2019, were included on initial review (figure 1). These dates were chosen based on the initiation of electronic medical records at the study's hospitals.

\section{Diagnostic criteria}

Patients with a definite diagnosis of PML were identified using diagnostic criteria previously published by the American Academy of Neurology (AAN). ${ }^{21}$ For patients with available histopathology, this included the presence of demyelination, bizarre astrocytes, enlarged oligodendroglial nuclei, and either positive tissue PCR for JC virus, positive immunohistochemistry, or visualization of viral particles using electron microscopy. For patients without histopathology, this included the presence of compatible clinical features, compatible radiologic findings, and a positive CSF PCR for JC virus. Patients whose available medical records were limited to histopathology results without clinical data were excluded from analysis. All included patients were diagnosed and treated by a neurologist before the authors' electronic medical records review.

\section{Data collection and variables}

Data on the initial clinical presentation and follow-up, until a censoring date of June 1, 2019, were collected in a central database. Variables of interest included sex, date of birth, clinical outcome, date of PML-related symptom onset, date of PML diagnosis, HIV infection status, malignancy status, transplantation status, immunosuppressive medications, CSF profile, JC virus positivity in serum and CSF, JC virus copy number or index value, and PML treatment modalities pursued. Previously published clinical diagnostic criteria were used to identify patients who developed immune reconstitution inflammatory syndrome (IRIS) ${ }^{22}$ For patients who were HIV infected, CD4 count and HIV viral load at the time of PML diagnosis were included. Presenting symptoms were reviewed and categorized. 


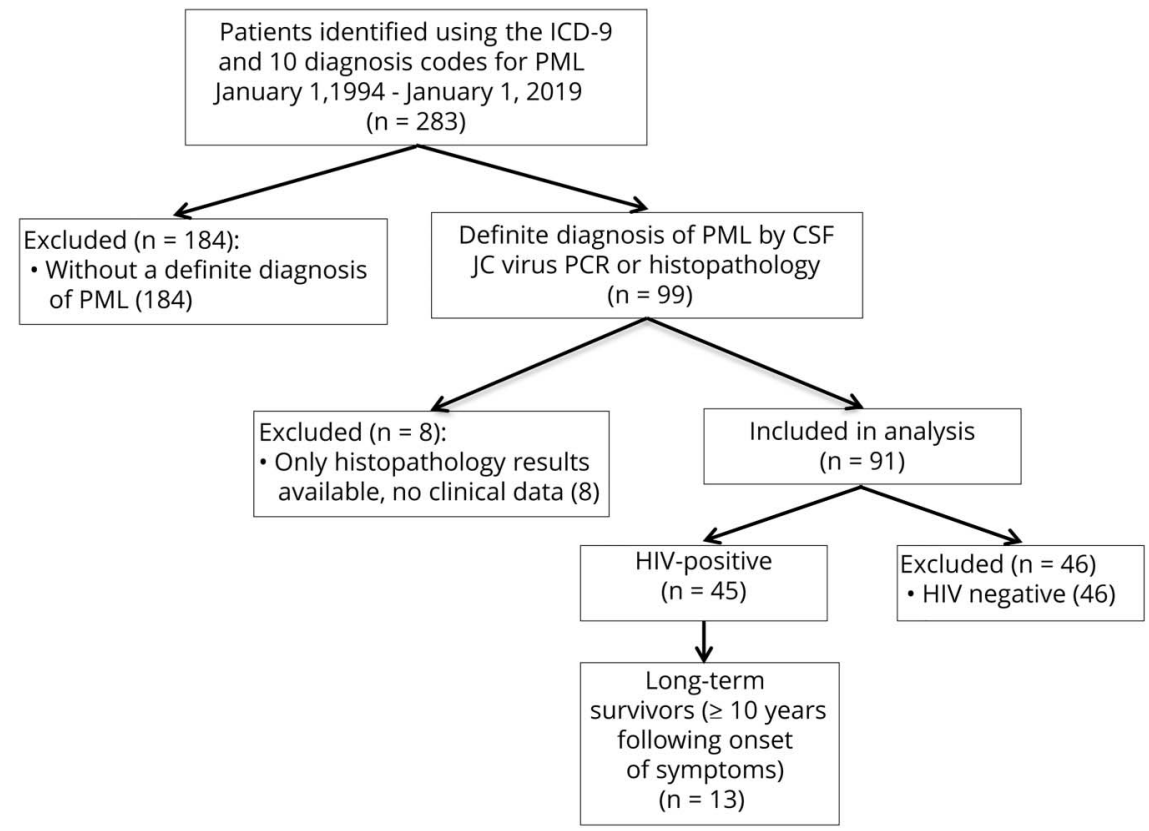

The first brain MRI obtained for each patient after the onset of symptoms were reviewed by a study neurologist (P.A.) and coded with respect to multifocality, presence or absence of gadolinium enhancement, and the anatomic location of lesions. Histopathology reports obtained through brain biopsy or autopsy were reviewed and coded with respect to the presence or absence of demyelination, bizarre astrocytes, enlarged oligodendroglial nuclei, tissue PCR, immunohistochemistry, and visualization of viral particles using electron microscopy. All treatments administered for PML were recorded for each patient.

For patients for whom a date of death was not recorded, a search of the US Social Security Administration Death Master File and the Massachusetts Registry of Vital Records and Statistics was performed to determine the date of death. For patients who remained alive as of April 1, 2019, a modified Rankin Scale (mRS) score was calculated at the last clinical follow-up. Patients who had last been seen by a neurologist more than 1 year earlier had an $\mathrm{mRS}$ determined through a telephone assessment. Patients who were diagnosed with PML on June 1, 2009, or earlier were eligible to be 10 -year survivors in this study.

\section{Statistical analysis}

All analyses were completed using Microsoft Excel ${ }^{\mathrm{TM}}$ and Python 2.7.14. Patient characteristics were summarized by expressing categorical variables as counts and proportions and continuous variables as medians. Major risk factors for PML were studied for prevalence in 5-year epochs, beginning with the study observation period's first observed time point on January 1, 1994, and counted as every 5 years afterward.
Patients with HIV infection were compared with all those without HIV infection using the 2-proportion z-test for differences in proportions, the unequal variance $t$-test for differences in means, and the Kruskal-Wallis test for differences in medians.

A Kaplan-Meier estimator was used to graph the survival of patients from the time of PML diagnosis to either death or the date of last known follow-up. The median survival was compared between HIV-infected and non-HIV-infected patients using a log-rank test. A $p$ value of 0.05 or less was considered statistically significant.

\section{Data availability}

Data will be made available upon reasonable request by qualified investigators and subject to ethics board approvals.

\section{Results}

\section{Patient characteristics}

There were 91 patients $(n=53,58 \%$ male $)$ with confirmed PML with a median age at symptomatic onset of 53 years (range 24-80 years) (table 1). HIV-infected PML patients were younger at the time of symptomatic onset, with a median age of 42 years compared with 67 years in HIV-uninfected patients ( $p$ $<0.001)$. HIV-infected patients were more often male $(71 \%, \mathrm{n}$ = 32) compared with HIV-uninfected patients $(46 \%, \mathrm{n}=21)(p$ $=0.014)$. The most common presenting symptoms observed were hemiparesis and gait and speech abnormalities.

The median time between symptomatic onset and diagnosis of PML was 40 days, with a minimum time of 5 days and a maximum time of 2 years, the latter in a patient with 
Table 1 Cohort characteristics, January 1, 1994, to January 1, $2019(n=91)$

\begin{tabular}{lll}
\hline Cohort characteristics $(\mathbf{n}=\mathbf{9 1})$ & $\mathbf{n}$ & $\mathbf{\%}$ \\
\hline Male & 53 & 58 \\
\hline Age at onset of PML symptoms $(\mathbf{y})$ & & \\
\hline $\mathbf{2 0 - 3 0}$ & 6 & 7 \\
\hline $\mathbf{3 1 - 4 0}$ & 15 & 16 \\
\hline $\mathbf{4 1 - 5 0}$ & 20 & 22 \\
\hline $\mathbf{5 1 - 6 0}$ & 14 & 15 \\
\hline $\mathbf{6 1 - 7 0}$ & 24 & 26 \\
\hline $\mathbf{7 1 - 8 0}$ & 12 & 13 \\
\hline
\end{tabular}

Status at last follow-up

\begin{tabular}{|c|c|c|}
\hline Deceased & 63 & 69 \\
\hline Alive & 27 & 30 \\
\hline Median mRS at last follow-up & 2 & \\
\hline Lost to follow-up & 1 & 1 \\
\hline \multicolumn{3}{|l|}{ Risk factors for PML ${ }^{\mathrm{a}}$} \\
\hline HIV infection & 45 & 49 \\
\hline Median CD4 cell count at diagnosis & 106 cells/mL & \\
\hline $\begin{array}{l}\text { Median plasma HIV viral load at } \\
\text { diagnosis }\end{array}$ & $\begin{array}{l}72,500 \text { copies/ } \\
\mathrm{mL}\end{array}$ & \\
\hline Chemotherapy $^{b}$ & 27 & 30 \\
\hline Lymphoma, leukemia, or myelodysplasia & 28 & 31 \\
\hline Bone marrow or stem cell transplant & 3 & 3 \\
\hline Monoclonal antibodyc & 17 & 19 \\
\hline MS disease-modifying drug ${ }^{d}$ & 4 & 4 \\
\hline Other innate immunodeficiency ${ }^{e}$ & 7 & 8 \\
\hline Rheumatologic disease $^{f}$ & 8 & 9 \\
\hline Rheumatologic disease-modifying drugg & 8 & 9 \\
\hline Carcinoma & 6 & 7 \\
\hline Solid organ transplant & 3 & 3 \\
\hline Splenectomy & 2 & 2 \\
\hline
\end{tabular}

Presenting symptoms ${ }^{a}$

\begin{tabular}{lll}
\hline Aphasia & 13 & 14 \\
\hline Apraxia & 4 & 4 \\
\hline Diminished level of consciousness & 1 & 1 \\
\hline Dysarthria & 17 & 19 \\
\hline Dysmetria & 15 & 16 \\
\hline Gait instability & 23 & 25 \\
\hline Headache & 4 & 4 \\
\hline Hemiparesis & 28 & 31 \\
\hline
\end{tabular}

Table 1 Cohort characteristics, January 1, 1994, to January 1, 2019 ( $n=91)$ (continued)

\begin{tabular}{lll}
\hline Cohort characteristics $(\mathbf{n}=\mathbf{9 1})$ & $\mathbf{n}$ & $\mathbf{\%}$ \\
\hline Memory impairment & 11 & 12 \\
\hline Neglect & 2 & 2 \\
\hline Psychiatric symptoms & 2 & 2 \\
\hline Seizure & 8 & 9 \\
\hline Sensory symptoms & 5 & 5 \\
\hline Tremor & 2 & 2 \\
\hline Vertigo & 9 & 10 \\
\hline Vision changes & 11 & 12 \\
\hline MRI findings ${ }^{\mathbf{a}}$ & & 71 \\
\hline Multifocality of lesions & 65 & 45 \\
\hline Posterior fossa involvement & 41 & 27 \\
\hline Enhancement with gadolinium & 25 & 7 \\
\hline Mass effect & 6 & 35 \\
\hline Method of diagnosis & & \\
\hline CSF JC virus PCR & 32 & \\
\hline Histopathologic triad & & 71 \\
\hline
\end{tabular}

Abbreviations: $\mathrm{mRS}=$ modified Rankin Scale; $\mathrm{PML}=$ progressive multifocal leukoencephalopathy.

a patients may fall into multiple categories.

${ }^{\mathrm{b}}$ Includes busulfan, bendamustine, cyclophosphamide, doxorubicin, and fludarabine.

' Includes brentuximab, rituximab, ofatumumab, and alemtuzumab.

${ }^{\mathrm{d}}$ Includes dimethyl fumarate and natalizumab.

e'Includes common variable immunodeficiency, cytopenias, and hypogammaglobulinemia.

${ }_{\mathrm{f}}^{\mathrm{f}}$ Includes sarcoidosis, granulomatous polyangiitis, systemic lupus erythematosus, and rheumatoid arthritis.

$\mathrm{g}$ Includes adalimumab, plaquenil, mycophenolate mofetil, corticosteroids, azathioprine, and methotrexate.

idiopathic lymphopenia. Time to diagnosis was shorter in HIV-infected patients vs HIV-uninfected patients, but this was not statistically significant (32 vs 48 days, $p=0.199$ ). Among patients with lymphoma, leukemia, or myelodysplasia, the median time to diagnosis was 48 days. Seventeen patients had a JC viral copy number tested in CSF at the time of PML diagnosis, with a median of 2,430 copies.

\section{PML risk factors}

The major predisposing factors for PML are reported in table 1 , with risk factors categorized by 5-year epoch reported in table 2. HIV infection was the most common risk factor, identified in $49 \%$ of the 91 patients. Other frequent risk factors included lymphoma, leukemia, or myelodysplasia, identified in $31 \%$ of patients $(\mathrm{n}=28)$, exposure to chemotherapeutic medications $(30 \%, \mathrm{n}=27)$, and exposure to monoclonal antibody therapies $(19 \%, \mathrm{n}=17)$. Several patients had exposure to multiple risk factors; for instance, 20 patients with lymphoma, leukemia, or myelodysplasia were 
Table 2 Number of patients affected by various risk factors for progressive multifocal leukoencephalopathy, separated based on year of progressive multifocal leukoencephalopathy symptom onset

\begin{tabular}{|c|c|c|c|c|c|}
\hline Risk factor ${ }^{a}$ & $\begin{array}{l}1994-1998 \\
(n=9)\end{array}$ & $\begin{array}{l}1999-2003 \\
(n=14)\end{array}$ & $\begin{array}{l}2004-2008 \\
(n=32)\end{array}$ & $\begin{array}{l}2009-2013 \\
(n=11)\end{array}$ & $\begin{array}{l}2014-2018 \\
(n=25)\end{array}$ \\
\hline HIV infection & 6 & 9 & 18 & 5 & 7 \\
\hline Rheumatologic disease & 0 & 0 & 1 & 0 & 7 \\
\hline $\begin{array}{l}\text { Lymphoma, leukemia, or } \\
\text { myelodysplasia }\end{array}$ & 3 & 3 & 11 & 3 & 8 \\
\hline Splenectomy & 0 & 0 & 2 & 0 & 0 \\
\hline Carcinoma & 0 & 0 & 4 & 0 & 2 \\
\hline Bone marrow or stem cell transplant & 0 & 1 & 0 & 0 & 2 \\
\hline Solid organ transplant & 0 & 1 & 0 & 0 & 2 \\
\hline Other innate immunodeficiency & 0 & 0 & 3 & 1 & 3 \\
\hline MS disease-modifying drug & 0 & 0 & 0 & 1 & 3 \\
\hline Monoclonal antibody & 0 & 1 & 7 & 3 & 6 \\
\hline Chemotherapy & 3 & 3 & 12 & 3 & 6 \\
\hline $\begin{array}{l}\text { Rheumatologic disease-modifying } \\
\text { drug }\end{array}$ & 0 & 0 & 1 & 0 & 7 \\
\hline
\end{tabular}

a Patients may have been exposed to multiple risk factors.

also exposed to chemotherapeutic medications, 3 had bone marrow or stem cell transplants, and 1 had comorbid HIV infection. Eight patients had underlying rheumatologic diseases, including sarcoidosis, granulomatous polyangiitis, systemic lupus erythematosus, and rheumatoid arthritis. All these patients were treated with disease-modifying therapies, including adalimumab, plaquenil, mycophenolate mofetil, corticosteroids, azathioprine, and/or methotrexate. One patient, diagnosed in 2002 and deceased 2 months later, had no known risk factors at the time of PML symptom onset; however, extensive immunologic and hematologic evaluations were not undertaken in this patient.

Among the 3 patients with solid organ transplants, 1 had undergone a double-lung transplant 4 years before the onset of PML symptoms, followed by a combined double-lung and kidney transplant 2 months before symptom onset for cystic fibrosis; 1 had undergone a single kidney transplant 19 years before symptom onset and was awaiting a liver transplant for hepatorenal syndrome secondary to alcoholic cirrhosis; and 1 had undergone an orthotopic heart transplant for nonischemic cardiomyopathy 2 years before the onset of symptoms.

Among the 3 patients with bone marrow and stem cell transplants, 1 had undergone a stem cell transplant 10 years before the onset of PML symptoms for chronic lymphocytic leukemia, followed by treatment with cyclophosphamide, vincristine, prednisone, and fludarabine for recurrent leukemia beginning 2 years before symptom onset complicated by pancytopenia; 1 had undergone a bone marrow transplant for
non-Hodgkin lymphoma 2 years before symptom onset, followed by treatment with cyclophosphamide, rituximab, and radiation 1 year before symptom onset; and 1 had undergone autologous stem cell transplant 4 years before symptom onset and allogenic stem cell transplant for relapsed disease 2 years before symptom onset, followed by therapy with rituximab and brentuximab for graft vs host disease beginning 3 months before symptom onset.

Four patients with a diagnosis of RRMS were included in the cohort. One patient had been treated with dimethyl fumarate since diagnosis with RRMS 3 years before the onset of PML symptoms. Three patients were treated with natalizumab. One patient had been on natalizumab for 3 years before the onset of PML symptoms and had previously been treated with interferon beta-1a and glatiramer acetate; 1 patient had been on natalizumab for 8 years before symptom onset and had been previously treated with interferon beta- $1 \mathrm{~b}$ and glatiramer acetate; and 1 patient had been on natalizumab for 1 year before symptom onset and had previously been treated with interferon beta-1a and glatiramer acetate. All 4 patients with RRMS were alive as of the censoring date, with durations of follow-up between 4 and 7 years. Three presented with new neurologic symptoms, including dysarthria, dysmetria, gait instability, headache, and visual changes. One was asymptomatic and was evaluated for PML because of changes seen on a surveillance brain MRI.

\section{Survival analysis}

Vital status could not be ascertained in 1 patient, who was excluded from the analysis of final outcomes. Thirty percent of 
the cohort was alive at the time of censoring (27/90), with a median $\mathrm{mRS}$ of 2 points (slight disability) at last follow-up. Eight patients had an mRS of 0 points (no symptoms, 30\%), 5 had an mRS of 1 point (no significant disability, 19\%), 6 had an mRS of 2 points (slight disability, 22\%), 1 had an mRS of 3 points (moderate disability, 4\%), 4 had an mRS of 4 points (moderately severe disability, 15\%), and 3 had an mRS of 5 points (severe disability, 11\%). One patient was diagnosed on the day of death. Median survival following PML was longer in patients who were HIV-infected patients (1,992 days) compared with patients who were HIV uninfected (101 days, $p=$ 0.024) (figure 2).

Forty patients survived more than 1 year after the onset of PML symptoms, of whom 24 were HIV infected (60\%). Thirty-three of $45 \mathrm{HIV}$-infected patients (73\%) and 24/46 HIV-uninfected patients (52\%) were diagnosed before June 1, 2009, and eligible for 10-year survivor status. Thirteen of 59 eligible patients survived more than 10 years after PML symptom onset (22\%). Ten-year survivors were all HIV infected, with either a new diagnosis of HIV at the time of PML diagnosis or nonadherence with previously prescribed combined antiretroviral therapy (cART) (table 3). Five 10year survivors were diagnosed with PML-IRIS following the PML diagnosis. Follow-up brain imaging in 10-year survivors predominantly revealed brain volume loss in areas that were previously involved by PML on initial imaging (figure 3). In addition to 10 -year survivors, 2 patients survived for more than 5 years after the onset of symptoms; 1 was HIV infected, and 1 had RRMS and exposure to natalizumab. No PML disease relapses were noted in any PML survivors.

\section{PML-directed treatment}

All HIV-infected patients were started on cART following PML diagnosis $(n=46)$. Thirty-seven percent $(n=34)$ of patients were treated with mirtazapine, and $15 \%(\mathrm{n}=14)$ were treated with mefloquine (table 4). Other therapies used in the treatment of PML included adoptive T-cell therapy, checkpoint inhibitor therapy, cidofovir, cytosine arabinoside, interferon alpha-2A, interleukin-2 inhibitor, IV immunoglobulins, and plasmapheresis. All 10-year survivors of PML were initiated on cART, and 1 was treated with cytosine arabinoside. No other PML-directed therapies were used in the treatment of patients who survived 10 or more years after PML symptom onset.

\section{Discussion}

Epidemiologic studies of PML remain rare despite the widespread awareness of the condition. Our findings demonstrate that, as PML is seen less often in HIV-infected individuals, new and repurposed immunosuppressive medications are increasingly recognized as predisposing factors for PML. Much attention has been focused in recent years on specific PML risk factors, including HIV infection and the use of natalizumab therapy in patients with RRMS. Although our study is not

Figure 2 The Kaplan-Meier estimator demonstrating survival following progressive multifocal leukoencephalopathy diagnosis in HIV-infected and HIV-uninfected patients ${ }^{a, b}$

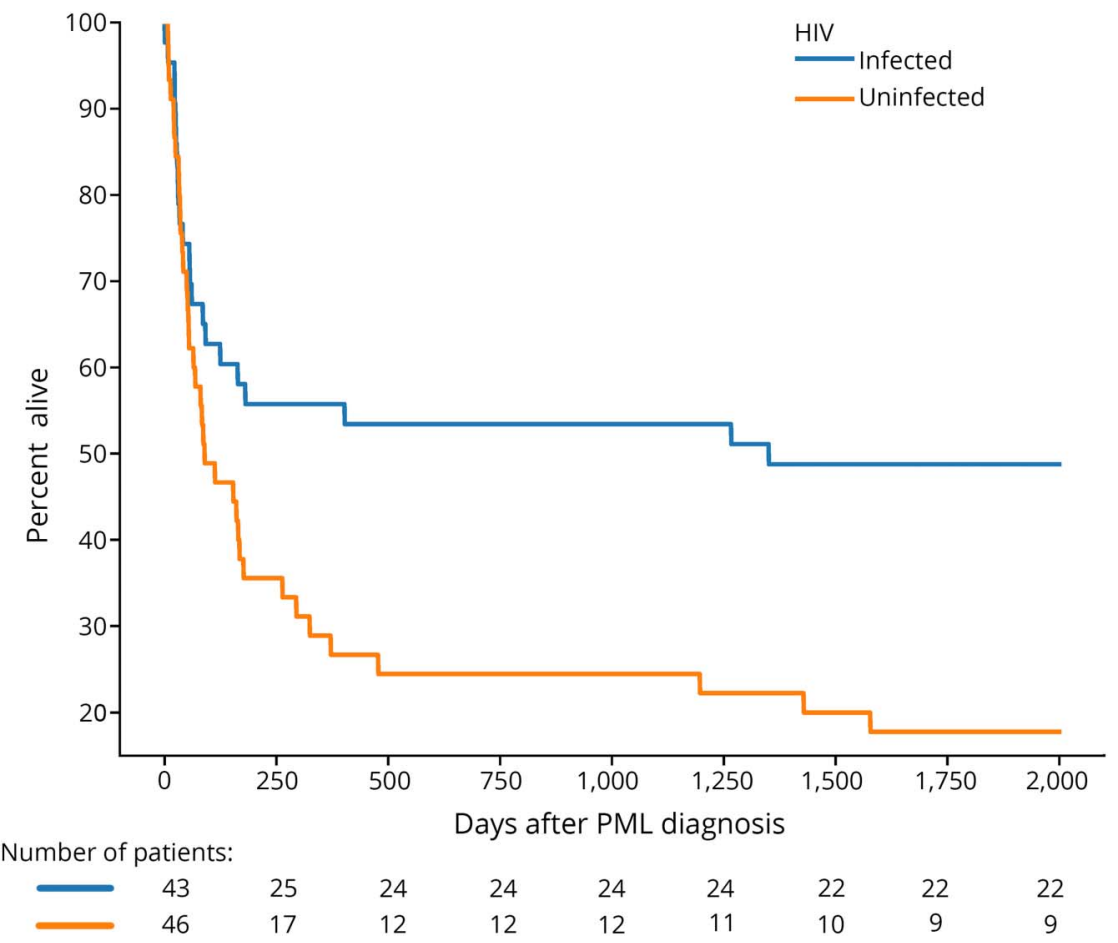

avital status could not be obtained for 1 patient, who was excluded from analysis. ${ }^{b}$ A second patient was deceased on day 0 of diagnosis. 
Table 3 Characteristics of patients who survived 10 or more years after the onset of PML symptoms ${ }^{a}$

\begin{tabular}{|c|c|c|c|c|c|c|c|c|c|}
\hline Patient & $\begin{array}{l}\text { Sex, } \\
\text { decade } \\
\text { of life }\end{array}$ & $\begin{array}{l}\text { CD4 count at } \\
\text { PML diagnosis } \\
\left(\text { cells } / \mathrm{mm}^{3}\right)\end{array}$ & $\begin{array}{l}\text { Viral load at } \\
\text { PML diagnosis } \\
\text { (copies/mL) }\end{array}$ & $\begin{array}{l}\text { Duration of } \\
\text { follow-up after } \\
\text { PML diagnosis } \\
\text { (y) }\end{array}$ & $\begin{array}{l}\text { mRS at } \\
\text { last } \\
\text { follow- } \\
\text { up }\end{array}$ & $\begin{array}{l}\text { CART } \\
\text { administered }\end{array}$ & $\begin{array}{l}\text { HIV status at } \\
\text { the time of } \\
\text { PML } \\
\text { diagnosis }^{b}\end{array}$ & $\begin{array}{l}\text { PML- } \\
\text { IRIS } \\
\text { or } \\
\text { not }\end{array}$ & $\begin{array}{l}\text { PML- } \\
\text { directed } \\
\text { therapy }\end{array}$ \\
\hline 1 & $\begin{array}{l}\text { M, } \\
\text { second }\end{array}$ & 90 & 78,000 & 14 & 1 & EFV, FTC, TDF & $\mathrm{N}$ & $\mathrm{Y}$ & $\mathrm{N}$ \\
\hline 2 & $\begin{array}{l}\text { F, } \\
\text { fourth }\end{array}$ & 43 & Unavailable & 11 & 6 & RTV, ddl & $A$ & $\mathrm{~N}$ & $\mathrm{~N}$ \\
\hline 3 & M, fifth & 130 & Unavailable & 20 & 6 & ZDV, ddl & $A$ & $\mathrm{~N}$ & $\begin{array}{l}\text { Cytosine } \\
\text { arabinoside }\end{array}$ \\
\hline 4 & M, third & 36 & 750,000 & 18 & 0 & $\begin{array}{l}\mathrm{d} 4 \mathrm{~T}, 3 \mathrm{TC}, \mathrm{ABC} \\
\mathrm{NVP}\end{array}$ & $A$ & $\mathrm{~N}$ & $\mathrm{~N}$ \\
\hline 5 & $\begin{array}{l}\text { M, } \\
\text { fourth }\end{array}$ & 103 & 421,000 & 17 & 2 & ZDV, 3TC, NFV & $\mathrm{N}$ & $\mathrm{Y}$ & $\mathrm{N}$ \\
\hline 6 & $\begin{array}{l}M, \\
\text { fourth }\end{array}$ & 241 & 153,000 & 17 & 1 & ZDV, ЗTC, EFV & A & $\mathrm{N}$ & $\mathrm{N}$ \\
\hline 7 & F, third & 20 & 182,000 & 15 & 0 & $\begin{array}{l}\text { ZDV, 3TC, RTV, } \\
\text { LPV }\end{array}$ & $\mathrm{N}$ & $\mathrm{N}$ & $\mathrm{N}$ \\
\hline 8 & $\begin{array}{l}\text { M, } \\
\text { fourth }\end{array}$ & 71 & 500,000 & 15 & 0 & RTV, ATV, TAF & $A$ & $\mathrm{~N}$ & $\mathrm{~N}$ \\
\hline 9 & $F$, third & 493 & Unavailable & 14 & 2 & NVP, FTC, TDF & A & $\mathrm{Y}$ & $\mathrm{N}$ \\
\hline 10 & $F$, third & 243 & Undetectable & 14 & 4 & $\begin{array}{l}\text { FTC, ATV, RTV, } \\
\text { TDF }\end{array}$ & $A$ & $\mathrm{~N}$ & $\mathrm{~N}$ \\
\hline 11 & $\begin{array}{l}M, \\
\text { fourth }\end{array}$ & 190 & 40,700 & 13 & 0 & $\begin{array}{l}\text { LPV, RTV, 3TC, } \\
\text { ZDV }\end{array}$ & $\mathrm{N}$ & $\mathrm{N}$ & $\mathrm{N}$ \\
\hline 12 & M, fifth & 130 & 803,000 & 12 & 2 & ATV, TDF, FTC & $A$ & $\mathrm{Y}$ & $\mathrm{N}$ \\
\hline 13 & M, fifth & 108 & 81 & 12 & 4 & $\begin{array}{l}\text { LPV, RTV, FTC, } \\
\text { TDF }\end{array}$ & $\mathrm{N}$ & $Y$ & $\mathrm{~N}$ \\
\hline
\end{tabular}

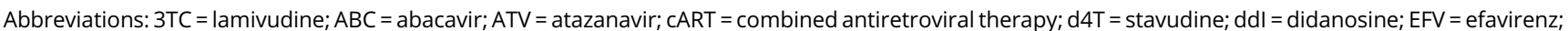
FTC = emtricitabine; IRIS = immune reconstitution inflammatory syndrome; LPV = lopinavir; mRS = modified Rankin Scale; NFV = nelfinavir; NVP = nevirapine; $\mathrm{PML}$ = progressive multifocal leukoencephalopathy; RTV = ritonavir; TAF = tenofovir alafenamide; TDF = tenofovir disoproxil fumarate; ZDV = zidovudine. ${ }^{\text {a }}$ All 10-year survivors were HIV infected.

${ }^{\mathrm{b}} \mathrm{N}=$ new diagnosis of HIV at the time of PML diagnosis, $\mathrm{A}=$ known HIV, nonadherent with cART at the time of PML diagnosis.

population based and does not report on incidence, we provide granular clinical data from 2 large academic tertiary care hospitals to elucidate the etiologies and outcomes for PML patients. We show here that despite previous interest in single medications or disease processes, PML occurs due to a broad range of risk factors that are often multiple and overlapping. This includes patients who both have underlying risk such as malignancy or rheumatologic disease and are exposed to 1 or more immunosuppressive medications.

Previous large cohort studies have focused on HIV infection as a predisposing risk factor for PML and have shown a decrease in the incidence of PML in HIV-infected patients with the advent of cART. In the pre-cART era, 1 study of $79 \mathrm{HIV}$ infected patients diagnosed between 1979 and 1983 at a single center found that $3.8 \%$ had PML. ${ }^{23}$ A Danish cohort of $47 \mathrm{HIV}$ infected patients with PML identified during the pre-cART (1995-1996), early cART (1997-1999), and late cART (2000-2006) periods found that although the incidence of
PML in HIV-infected patients had decreased, survival remained poor, with a median duration of 146 days. ${ }^{24}$ A prospective French study of 92,477 HIV-infected patients followed between 1997 and 2011 found that 555 developed PML, with a decrease in incidence of $57 \%$ over the 15 -year study period. ${ }^{25}$ The Swiss HIV cohort followed $186 \mathrm{HIV}$-infected patients with PML and found a decrease in PML incidence and mortality associated with cART independent of baseline CD4 T-cell count. ${ }^{26}$ Here, we find that the median survival following PML in HIV-infected patients is longer than in HIV-uninfected patients $(1,992$ vs 101 days, $p=0.024)$. The most common presenting symptoms in our cohort, hemiparesis and gait and speech abnormalities, reflect those described in the largest HIV-PML cohort described in the literature. ${ }^{2}$

Limited literature exists on longer-term survivors of PML. A 2010 study described the clinical outcome of 24 patients with PML whose survival exceeded 5 years, demonstrating that the majority of survivors improved or were stable in their deficits 


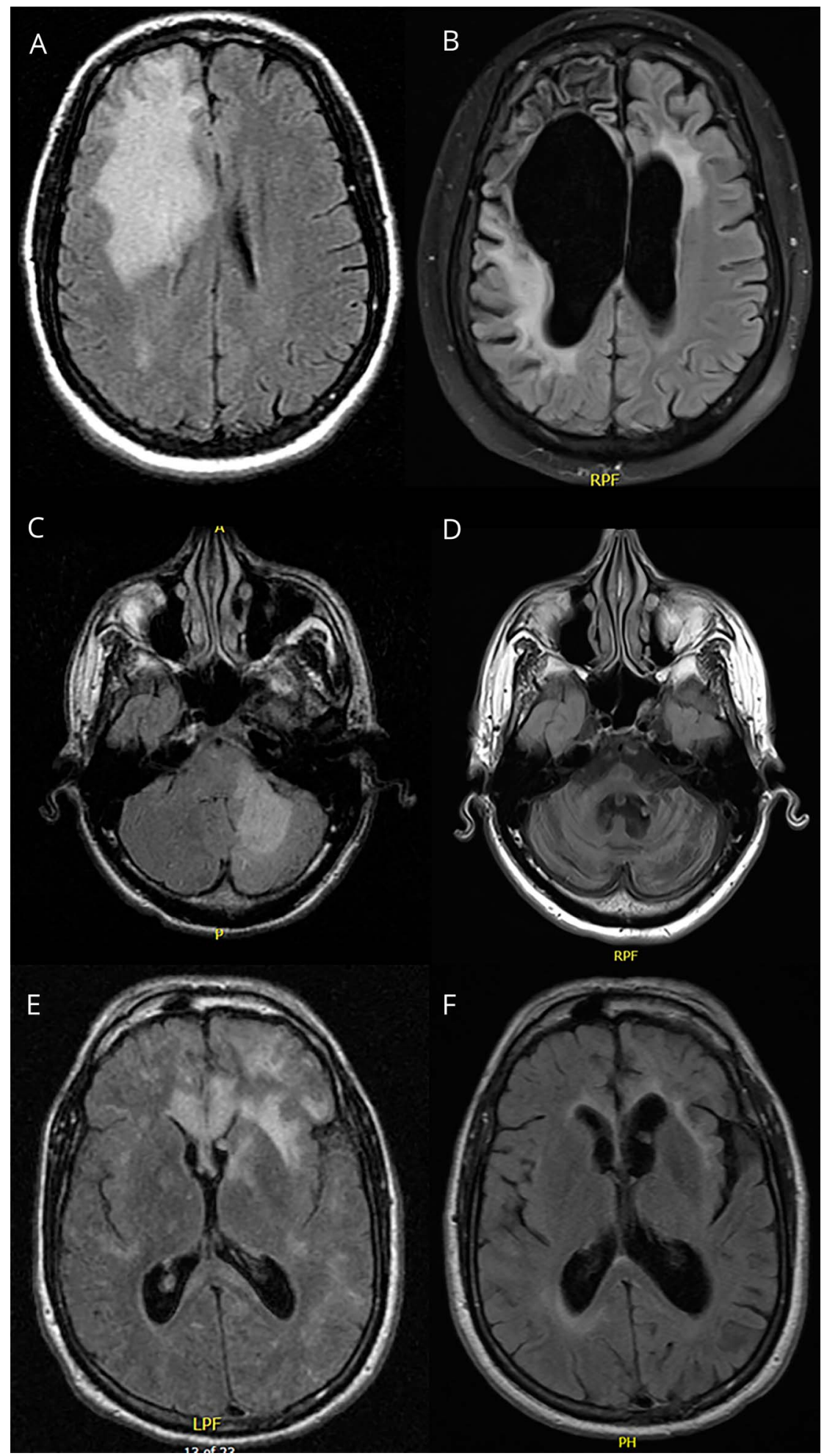

Case 1: A 37-year-old HIV-infected woman was nonadherent with her combined antiretroviral therapy for 2 years and presented with dysarthria and left hand clumsiness. (A) T2-weighted fluid attenuation inversion recovery (FLAIR) sequences revealed a large zone of hyperintensity involving the right frontal lobe, extending into the deep white matter and sparing the cortical ribbon. (B) Followup MRI 12 years later demonstrated tissue loss involving the right frontal lobe with associated ex vacuo dilatation of the frontal horn of the right lateral ventricle. Case 2: a 39-year-old HIV-infected man presented with gait ataxia and falls. (C) MRI revealed T2-FLAIR hyperintensity predominantly involving the left cerebellar hemisphere. (D) Followup MRI 12 years later demonstrated severe cerebellar and brainstem volume loss. Case 3: a 48year-old injection drug user presented with behavioral changes, seizures, and aphasia and was found to be HIV infected. (E) MRI revealed multifocal areas of subcortical T2/FLAIR hyperintensity. (F) Follow-up MRI 10 years later revealed asymmetric volume loss. $\mathrm{PML}=$ progressive multifocal leukoencephalopathy.

after 5 years from onset of symptoms. ${ }^{27}$ As in our study, the majority of long-term survivors of PML were found to be HIV infected. Here, we report on the outcomes of thirteen 10 -year survivors of PML out of 59 patients who were followed for 10 or more years after the onset of symptoms, including 1 patient followed at our center for $>18$ years. We have performed nearly a complete case analysis, with only 1 patient lost to follow-up, allowing for robust estimates of survival and functional outcome among survivors. All the 10-year PML survivors in our study were HIV infected, with 1 patient with RRMS who survived for 
Table 4 PML-directed therapies administered to the cohort

\begin{tabular}{|c|c|c|c|}
\hline PML-directed therapy administered ${ }^{a}$ & Number treated & $\begin{array}{l}\text { Number alive at } \\
\text { censoring date }\end{array}$ & Dosing and administration \\
\hline Adoptive T-cell therapy & 1 & 1 & Single IV transfusion \\
\hline Cidofovir & 8 & 2 & $5 \mathrm{mg} / \mathrm{kg}$ IV weekly for $2 \mathrm{wk}$, then biweekly \\
\hline Cytosine arabinoside & 2 & 0 & $4 \mathrm{mg} / \mathrm{kg}$ IV for $4-5 \mathrm{~d}$ \\
\hline Immunoglobulins & 9 & 2 & $300-2,000 \mathrm{mg} / \mathrm{kg}$ every 3-4 wk \\
\hline Interleukin-2 inhibitor & 3 & 0 & $\begin{array}{l}1 \text { million units SQ once, followed by } 1.8 \\
\text { million unit SQ daily }\end{array}$ \\
\hline Mefloquine & 14 & 5 & $250 \mathrm{mg}$ orally daily for $3 \mathrm{~d}$, then weekly \\
\hline Mirtazapine & 34 & 11 & $15-45 \mathrm{mg}$ orally given nightly \\
\hline Peginterferon alpha-2A & 3 & 0 & $180 \mu \mathrm{g}$ SQ weekly \\
\hline Pembrolizumab & 2 & 0 & 2 mg/kg IV given every 4-6 wk \\
\hline Plasmapheresis & 2 & 1 & Every other day for 5 sessions \\
\hline
\end{tabular}

Abbreviations: $\mathrm{PML}=$ progressive multifocal leukoencephalopathy; $\mathrm{SQ}=$ subcutaneously .

a Patients may have received multiple therapies.

more than 5 years following natalizumab-induced PML. As a more positive finding, the majority of PML survivors in our cohort had either no or slight disability at the time of follow-up, suggesting that those who survive can anticipate functional independence in most cases. These findings may help to inform prognostication in future cases of PML. Although multiple therapeutic options have been offered in the treatment of PML, all the 10-year survivors in our cohort were treated with cART, and just 1 received another PML-directed therapy.

We also identify a diagnostic delay, with a median time to diagnosis of 40 days. This finding replicates earlier studies demonstrating frequent misdiagnosis of PML, including a retrospective Swedish national study from 1988 to $2013 .^{28} \mathrm{~A}$ separate Boston-based retrospective study at a different institution covering the years 1993-2015 reported a median time from initial PML symptom onset to PML diagnosis of 74 days. ${ }^{29}$ In nearly two-thirds of patients, a different diagnosis was first considered. Our cohort included a patient with unexplained lymphopenia who was diagnosed with PML 2 years after the initial onset of symptoms. In an era of available PMLdirected therapy, this delay may affect clinical outcomes.

In part, this delay may be fueled by stringent criteria for a diagnosis of PML. A Dutch-Belgian cohort of 28 patients with PML found that 18 patients met the AAN criteria ${ }^{21}$ for high diagnostic certainty for PML at initial evaluation, which increased to 20 patients on follow-up evaluation. ${ }^{30}$ The remainder of the cohort was classified as either "possible PML" or "not PML" despite a very high suspicion for PML based on MRI characteristics. A second study of 128 patients with PML in the setting of natalizumab exposure found that JC virus detection in CSF had a poor sensitivity for the diagnosis of early PML. ${ }^{31}$ Earlier proposed criteria were formulated for patients with exposures to specific risk factors. ${ }^{32}$ These failed to account for exposures to a diverse profile of overlapping risk factors.

Our study is limited by its retrospective nature. It is also subject to referral bias. In particular, the hospitals included in this analysis are both tertiary care centers and may be enriched for an oncologic population, as well as for less common underlying risk factors and exposures. Our study did not include city- or state-wide data and did not capture data from the public hospitals in the region. Both hospitals primarily care for adult patients, and our data collection expectedly captured no pediatric cases. Although PML is rarely seen in children, pediatric cases are described in the literature. ${ }^{33}$ Our cases were subject to strict selection criteria: the requirement for CSF JC virus PCR positivity or histopathology to make a definitive diagnosis of PML. These criteria may have selected for more severe cases that proceeded to lumbar puncture or brain biopsy. Although this provides a high level of confidence in the accuracy of the diagnosis in included cases, our use of stringent criteria almost certainly underestimated the number of PML cases by eliminating cases that were based on neuroimaging findings alone. Finally, because we used a variety of sources to ascertain vital status at the censoring date, we are unable to comment on cause of death in our patient population. Patients who died with PML may not have died because of PML in all cases, particularly given the independent contribution of underlying risk factors.

Unlike other recent studies that result from drug safety programs or disease-specific entities, our work includes the range of risk profiles for PML in a large, academic, US setting. This adds to the limited literature comprising PML cohorts with large sample sizes. Survival following PML remains short for most patients at less than 2 months. However, long-term survivorship is possible in those with HIV infection and initiation 
of cART. Although we cannot conclude that any specific cART regimen was definitely effective for long-term survival, we present the regimens that have been successfully used at our center for patients with HIV-PML who survived 10 or more years after the onset of PML symptoms. We provide observational, retrospective data on a range of other attempted therapies in our patients for other researchers to include and synthesize across centers in future studies. Finally, our study offers a historical comparison for treatment cohorts as promising PML therapies enter into clinical trials. ${ }^{13-16}$

\section{Study funding}

No dedicated study funding.

\section{Disclosure}

P. Anand, G.C. Hotan, A. Vogel, and N. Venna report no disclosures. F.J. Mateen has consulted for Genentech Roche and Oxford Pharmagenesis, unrelated to the present work. Go to Neurology.org/NN for full disclosures.

\section{Publication history}

Received by Neurology: Neuroimmunology \& Neuroinflammation July 3, 2019. Accepted in final form August 13, 2019.

\section{Appendix Authors}

\begin{tabular}{llll}
\hline Name & Location & Role & Contribution \\
\hline $\begin{array}{l}\text { Pria } \\
\text { Anand, MD }\end{array}$ & $\begin{array}{l}\text { Massachusetts } \\
\text { General Hospital, } \\
\text { Boston }\end{array}$ & Author & $\begin{array}{l}\text { Design and } \\
\text { conceptualization of the } \\
\text { study; collection and } \\
\text { analysis of data; and } \\
\text { drafted the manuscript for } \\
\text { intellectual content }\end{array}$
\end{tabular}

\begin{tabular}{llll}
\hline $\begin{array}{l}\text { Gladia C. } \\
\text { Hotan, BS }\end{array}$ & $\begin{array}{l}\text { Massachusetts } \\
\text { Institute of } \\
\text { Technology, } \\
\text { Cambridge }\end{array}$ & Author & $\begin{array}{l}\text { Analysis and } \\
\text { interpretation of data and } \\
\text { revision of the manuscript } \\
\text { for intellectual content }\end{array}$ \\
\hline $\begin{array}{l}\text { Andre } \\
\text { Vogel, BA }\end{array}$ & $\begin{array}{l}\text { Massachusetts } \\
\text { General Hospital, } \\
\text { Boston }\end{array}$ & Author & $\begin{array}{l}\text { Acquisition of data and } \\
\text { revision of the manuscript } \\
\text { for intellectual content }\end{array}$ \\
\hline $\begin{array}{l}\text { Nagagopal } \\
\text { Venna, MD }\end{array}$ & $\begin{array}{l}\text { Massachusetts } \\
\text { General Hospital, }\end{array}$ & Author & $\begin{array}{l}\text { Acquisition of data and } \\
\text { revision of the manuscript } \\
\text { for intellectual content }\end{array}$ \\
\hline $\begin{array}{l}\text { Farrah J. } \\
\text { Mateen, } \\
\text { MD, PhD }\end{array}$ & $\begin{array}{l}\text { Massachusetts } \\
\text { General Hospital, } \\
\text { Boston }\end{array}$ & Author & $\begin{array}{l}\text { Design and } \\
\text { conceptualization of the } \\
\text { study; analysis of data; } \\
\text { revision of the manuscript } \\
\text { for intellectual content; } \\
\text { and study supervision }\end{array}$ \\
\hline & & &
\end{tabular}

\section{References}

1. Åström KE, Mancall EL, Richardson EP. Progressive multifocal leukoencephalopathy: a hitherto unrecognized complication o chronic lymphatic leukæmia and Hodgkin's disease. Brain 1958. doi:10.1093/brain/81.1.93.

2. Berger JR, Pall L, Lanska D, Whiteman M. Progressive multifocal leukoencephalopathy in patients with HIV infection. J Neurovirol 1998;4:59-68. doi:10.3109/13550289809113482.

3. Langer-Gould A, Atlas SW, Green AJ, Bollen AW, Pelletier D. Progressive multifocal leukoencephalopathy in a patient treated with natalizumab. N Engl J Med 2005;353: 375-381. doi:10.1056/nejmoa051847.

4. Kleinschmidt-DeMasters BK, Tyler KL. Progressive multifocal leukoencephalopathy complicating treatment with natalizumab and interferon beta-1a for multiple sclerosis. N Engl J Med 2005;353:369-374. doi:10.1056/nejmoa051782.
5. Clifford DB, Ances B, Costello C, et al. Rituximab-associated progressive multifocal leukoencephalopathy in rheumatoid arthritis. Arch Neurol 2011;68:1156-1164. doi: 10.1001/archneurol.2011.103.

6. Calabrese LH, Molloy ES. Progressive multifocal leucoencephalopathy in the rheumatic diseases: assessing the risks of biological immunosuppressive therapies. Ann Rheum Dis 2008;67(3 suppl):iii64-iii65. doi:10.1136/ard.2008.097972.

7. Berger JR, Houff S. Opportunistic infections and other risks with newer multiple sclerosis therapies. Ann Neurol 2009;65:367-377. doi:10.1002/ana.21630.

8. Aksamit AJ. Progressive multifocal leukoencephalopathy. Contin Lifelong Learn Neurol 2013. doi:10.1212/01.con.0000423852.70641.de.

9. Owczarczyk K, Hilker R, Brunn A, Hallek M, Rubbert A. Progressive multifocal leucoencephalopathy in a patient with sarcoidosis - successful treatment with cidofovir and mirtazapine. Rheumatology (Oxford) 2007;46:888-890. doi:10.1093/ rheumatology/kem049.

10. Razonable RR, Aksamit AJ, Wright AJ, Wilson JW. Cidofovir treatment of progressive multifocal leukoencephalopathy in a patient receiving highly active antiretroviral therapy. Mayo Clin Proc 2001;76:1171-1175. doi:10.4065/76.11.1171.

11. Hall CD, Dafni U, Simpson D, et al. Failure of cytarabine in progressive multifocal leukoencephalopathy associated with human immunodeficiency virus infection. AIDS Clinical Trials Group 243 Team. N Engl J Med 1998;338:1345-1351.

12. Skromne E, Rivera VM, Ontaneda D, Ordonez L. Progression of progressive multifocal leukoencephalopathy despite treatment with $\beta$-interferon. Neurology 2006;66: 1787-1788. doi:10.1212/01.wnl.0000230563.29202.6a.

13. Walter $\mathrm{O}$, Treiner E, Bonneville F, et al. Treatment of progressive multifocal leukoencephalopathy with nivolumab. N Engl J Med 2019;380:1674-1676. doi:10. 1056/NEJMc1816198.

14. Cortese I, Muranski P, Enose-Akahata Y, et al. Pembrolizumab treatment for progressive multifocal leukoencephalopathy. N Engl J Med 2019;380:1597-1605. doi:10. 1056/NEJMoa1815039.

15. Hoang E, Bartlett NL, Goyal MS, Schmidt RE, Clifford DB. Progressive multifocal leukoencephalopathy treated with nivolumab. J Neurovirol 2019;25:284-287. doi:10. 1007/s13365-019-00738-x.

16. Rezvani K, Marin D. Allogeneic BK virus-specific T cells for PML. N Engl J Med 2019;380:106. doi:10.1056/nejmc1815050.

17. Bloomgren G, Richman S, Hotermans $\mathrm{C}$, et al. Risk of natalizumab-associated progressive multifocal leukoencephalopathy. N Engl J Med 2012;366:1870-1880. doi:10. 1056/NEJMoa1107829.

18. Landi D, De Rossi N, Zagaglia S, et al. No evidence of beneficial effects of plasmapheresis in natalizumab-associated PML. Neurology 2017;88:1144-1152. doi:10. 1212/WNL.0000000000003740

19. Ruiz-Heredia Y, Sanchez-Vega B, Barrio S, et al. Concurrent progressive multifocal leukoencephalopathy and central nervous system infiltration by multiple myeloma: a case report. J Oncol Pharm Pract 2019;25:998-1002. doi:10.1177/1078155218769367.

20. Rastogi A, Gulati N, Bihari C, et al. JC virus-related progressive multifocal leukoencephalopathy after living-donor liver transplant: a rare case. Exp Clin Transpl 2017;17:414-417. doi:10.6002/ect.2016.0242.

21. Berger JR, Aksamit AJ, Clifford DB, et al. PML diagnostic criteria: consensus statement from the AAN neuroinfectious disease section. Neurology 2013;80:1430-1438

22. McCarthy M, Nath A. Neurologic consequences of the immune reconstitution in flammatory syndrome (IRIS). Curr Neurol Neurosci Rep 2010;10:467-475. doi:10. 1007/s11910-010-0138-y.

23. Krupp LB, Lipton RB, Swerdlow ML, Leeds NE, Llena J. Progressive multifocal leukoencephalopathy: clinical and radiographic features. Ann Neurol 1985;17: 344-349. doi:10.1002/ana.410170407.

24. Engsig FN, Hansen A-BE, Omland LH, et al. Incidence, clinical presentation, and outcome of progressive multifocal leukoencephalopathy in HIV-infected patients during the highly active antiretroviral therapy era: a nationwide cohort study. J Infect Dis 2009;199:77-83. doi:10.1086/595299.

25. Melliez H, Mary-Krause M, Bocket L, et al. Risk of progressive multifocal leukoencephalopathy in the combination antiretroviral therapy era in the French hospital database on human immunodeficiency virus (ANRS-C4). Clin Infect Dis 2018;67:275-282.

26. Khanna N, Elzi L, Mueller NJ, et al. Incidence and outcome of progressive multifocal leukoencephalopathy over 20 years of the Swiss HIV cohort study. Clin Infect Dis 2009;48:1459-1466. doi:10.1086/598335.

27. Lima MA, Bernal-Cano F, Clifford DB, Gandhi RT, Koralnik IJ. Clinical outcome of long-term survivors of progressive multifocal leukoencephalopathy. J Neurol Neurosurg Psychiatry 2010;81:1288-1291. doi:10.1136/jnnp.2009.179002.

28. Iacobaeus E, Burkill S, Bahmanyar S, et al. The National incidence of PML in Sweden, 1988-2013. Neurology 2018;90:e498-e506. doi:10.1212/WNL.0000000000004926 LK

29. Miskin DP, Ngo LH, Koralnik IJ. Diagnostic delay in progressive multifocal leukoencephalopathy. Ann Clin Transl Neurol 2016;3:386-391.

30. Wijburg MT, Warnke C, Barkhof F, Uitdehaag BMJ, Killestein J, Wattjes MP. Performance of PML diagnostic criteria in natalizumab-associated PML: data from the Dutch-Belgian cohort. J Neurol Neurosurg Psychiatry 2019.90:44-46.

31. Blankenbach K, Schwab N, Hofner B, et al. Natalizumab-associated progressive multifocal leukoencephalopathy in Germany. Neurology 2019;92:e2232-e2239. doi: 10.1212/WNL.0000000000007451.

32. Mentzer D, Prestel J, Adams O, et al. Case definition for progressive multifocal leukoencephalopathy following treatment with monoclonal antibodies. J Neurol Neurosurg Psychiatry 2012;83:927-933. doi:10.1136/jnnp-2012-302478.

33. Berger JR, Scott G, Albrecht J, Belman AL, Tornatore C, Major EO. Progressive multifocal leukoencephalopathy in HIV-1-infected children. AIDS 1992;6:837-841. doi:10.1097/00002030-199208000-00012. 


\section{Neurology \\ Neuroimmunology \& Neuroinflammation}

\section{Progressive multifocal leukoencephalopathy: A 25-year retrospective cohort study Pria Anand, Gladia C. Hotan, Andre Vogel, et al. \\ Neurol Neuroimmunol Neuroinflamm 2019;6; \\ DOI 10.1212/NXI.0000000000000618}

This information is current as of September 25, 2019

\section{Updated Information \& Services}

References

Citations

Subspecialty Collections

Permissions \& Licensing

Reprints including high resolution figures, can be found at: http://nn.neurology.org/content/6/6/e618.full.html

This article cites 31 articles, 4 of which you can access for free at: http://nn.neurology.org/content/6/6/e618.full.html\#\#ref-list-1

This article has been cited by 3 HighWire-hosted articles: http://nn.neurology.org/content/6/6/e618.full.html\#\#otherarticles

This article, along with others on similar topics, appears in the following collection(s):

HIV

http://nn.neurology.org//cgi/collection/hiv

Multiple sclerosis

http://nn.neurology.org//cgi/collection/multiple_sclerosis

Information about reproducing this article in parts (figures,tables) or in its entirety can be found online at:

http://nn.neurology.org/misc/about.xhtml\#permissions

Information about ordering reprints can be found online: http://nn.neurology.org/misc/addir.xhtml\#reprintsus

Neurol Neuroimmunol Neuroinflamm is an official journal of the American Academy of Neurology.

Published since April 2014, it is an open-access, online-only, continuous publication journal. Copyright

Copyright (C) 2019 The Author(s). Published by Wolters Kluwer Health, Inc. on behalf of the American

Academy of Neurology.. All rights reserved. Online ISSN: 2332-7812.

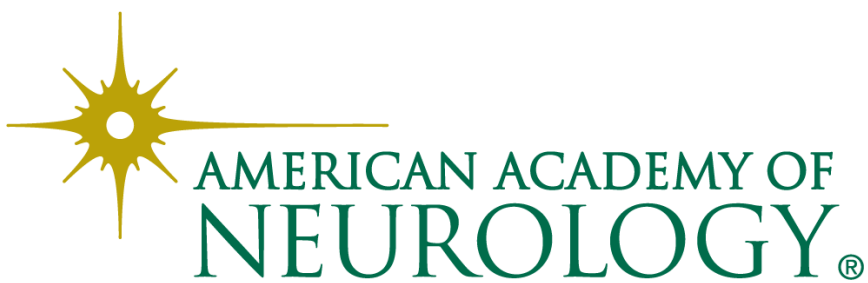

